\title{
BIRDS
}

\section{FIRST DOCUMENTED BREEDING RECORD OF WHITE-FACED IBIS IN MANITOBA}

RON BAZIN, Canadian Wildlife Service, 150-123 Main Street, Winnipeg, MB R3C 4W2, E-mail: ron.bazin @ ec.gc.ca, and CHRISTIAN ARTUSO, University of Manitoba, Department of Environment and Geography, Winnipeg, MB, R2T 2N2, Email: chartuso@gmail.com.

Ibis are curve-billed, long-legged wading birds that occur primarily in tropical and warm-temperate regions. Three ibis species occur in North America, two of which belong to the genus Plegadis (White-faced IbisPlegadis chihi and Glossy IbisPlegadis falcinellus) and show similar traits and colour patterns, which can potentially confound identification. Both
Plegadis ibis species are rare visitors to Manitoba, but the White-faced Ibis does occur with greater regularity.

The White-faced Ibis is a highly mobile species and breeding adults sometimes exhibit nomadic behaviour in addition to their regular north-south migrations. ${ }^{14,15}$ In response to the dynamic nature of their breeding

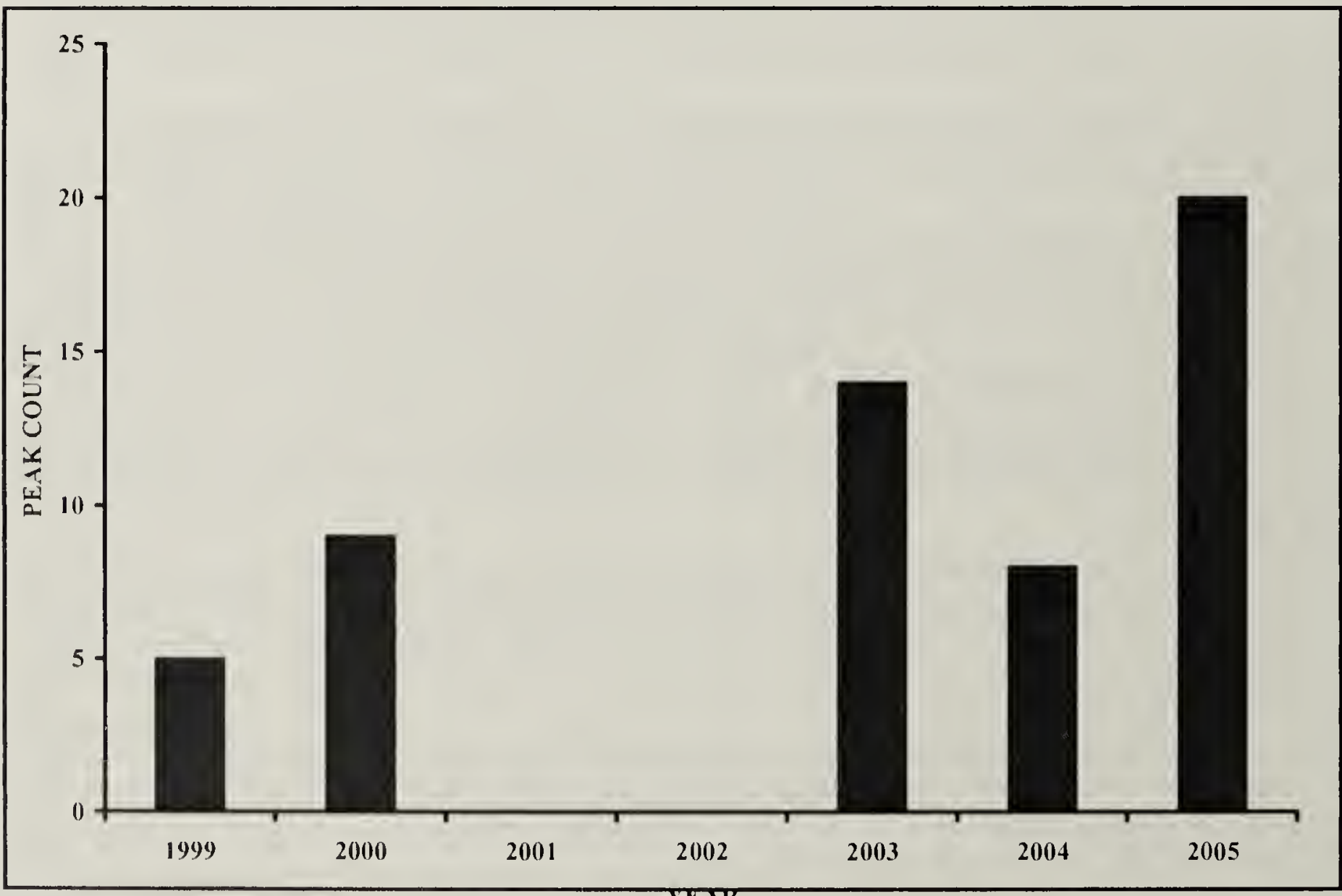

Fig.1. Peak counts of White-faced Ibis at Whitewater Lake between 1999 and 2005. 
habitat, which is prone to periodic drought or flooding, White-faced lbis will readily relocate to new nesting areas when conditions at their established colonies are less than favorable. ${ }^{15}$

Extra-limital observations of Whitefaced Ibis have occurred sporadically to the north of the core breeding range since the early 1900s. However, these observations increased in frequency during the second half of the 20th century, particularly in the northern Great Plains region. ${ }^{15}$ The range expansions that have occurred over the last three decades are attributed primarily to improved nesting habitat management, the banning of DDT and other pesticides and improved breeding success at major colonies. ${ }^{15}$

In Canada, the earliest confirmed record of the species was an immature specimen collected in 1907 in British Columbia. ${ }^{3}$ Across the prairies, the White-faced Ibis was first reported in Manitoba in 1934, Alberta in 1941 and
Saskatchewan in 1976. $3,9,11$ In Manitoba, only 4 of the 16 reports of Plegadis ibis between 1934 and 2001 occurred prior to 1989 , indicative of a more recent increasing trend over time. These observations occurred primarily along southern Lake Manitoba, at Oak Hammock Marsh and at Whitewater Lake. ${ }^{11}$

All of the Manitoba records from 1934 to 1998 involved single birds only. This changed in 1999 when up to five birds were observed at one time at Whitewater Lake over the course of the summer, increasing to a peak count of nine birds at the same location by 2000." Very few birds were observed anywhere in Manitoba in 2001 (one at Oak Hammock Marsh) and 2002 (five unconfirmed White-faced Ibis at Oak Lake), possibly as a result of drier conditions in the southern part of the province. ${ }^{11}$

White-faced Ibis returned to Whitewater Lake in greater numbers

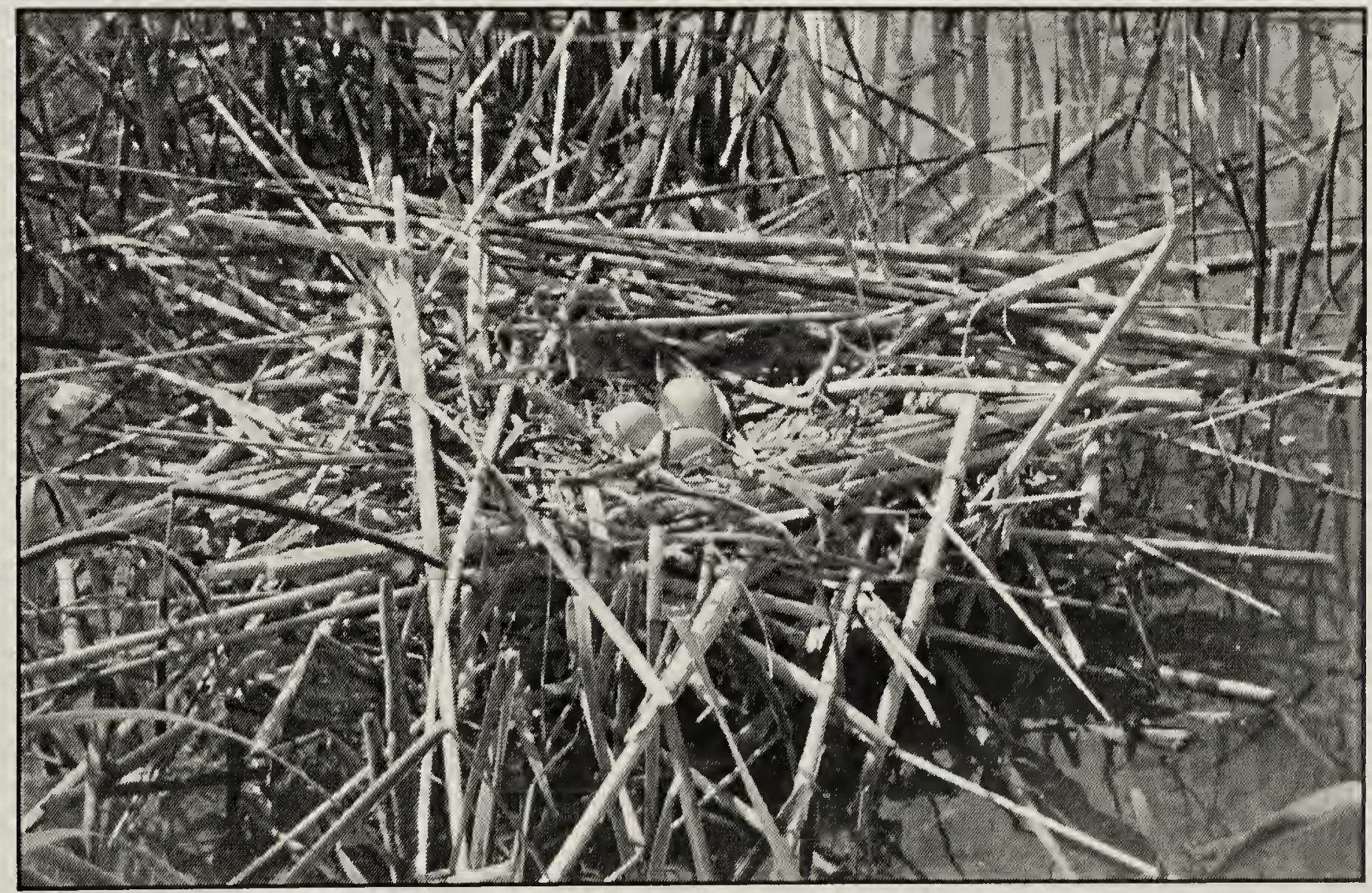

Fig.2. White-faced Ibis nest at Whitewater Lake, MB, July 7, 2005.

Ron Bazin 
from 2003 to 2005 (Fig. 1). ${ }^{6-8}$ The highest numbers ever recorded in Manitoba in a single year occurred in 2005 , a very wet year, with a peak count of $20+$ birds in May. 7,8 These peak counts suggested the possible presence of a small breeding colony at Whitewater Lake.

North and South Dakota recorded their first White-faced Ibis nesting colonies in 1978, at Long Lake and Sand Lake National Wildlife Refuges respectively. ${ }^{16-18}$ In Canada, White-faced lbis are known to breed in Alberta, at Stirling, Pakowki and Frank Lakes, and near Kininvie. The first confirmed nesting attempt occurred in 1982, followed by two attempts in 1986 and the first confirmed successful nesting in 1992. ${ }^{2,3}$ There is also a record of White-faced Ibis breeding in Saskatchewan at Old Wives Lake in July 2000 where a pair of adults and one young were observed ( $P$. Taylor, pers. comm., 3 May 2006). The White-faced Ibis is considered a rare breeder in Alberta and the Dakotas. ${ }^{4,12}$

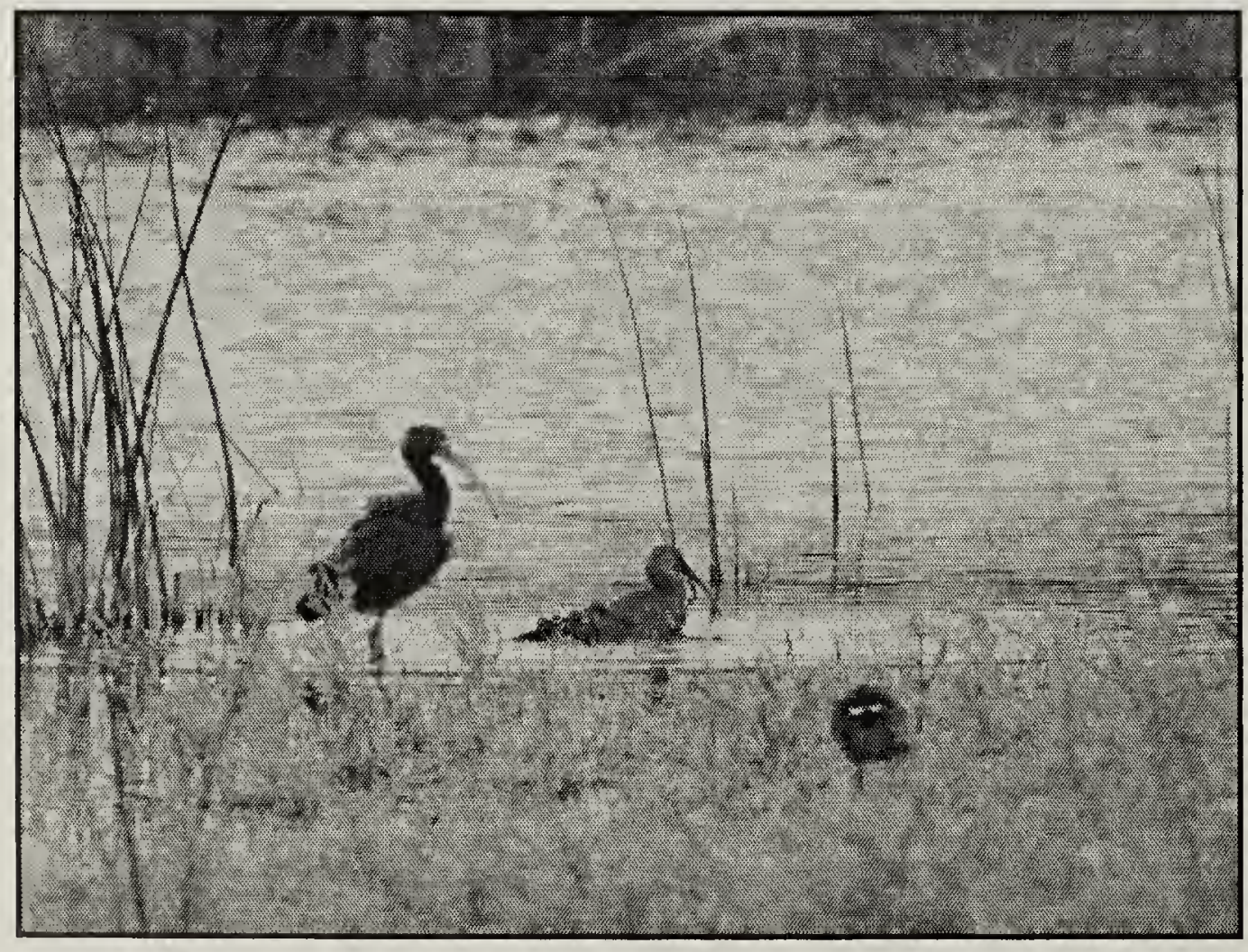

Fig. 3. An immature ibis and two adult White-faced lbis at Whitewater Lake, MB, September 11, 2005
Christian Artuso

Breeding habitat for the White-faced Ibis consists primarily of inland, mainly shallow marshes with patches of emergent vegetation within which nests are typically situated..$^{15}$ This description is consistent with that of Whitewater Lake, in southwestern Manitoba, where the majority of White-faced Ibis have been observed. ${ }^{10}$

Two nests were found by one of the authors (RB) while doing a Franklin's Gull survey at Whitewater Lake on July 7,2005 . The first nest was very large, roughly cylindrical in shape, standing moderately high above the water and contained three pale blue eggs with no markings (Fig. 2). The nest was constructed with both live and dead cattail (Typha sp.) which was the dominant vegetation in the area and which occurred in low to moderate density. This description of the nest and eggs is consistent with what is found in the literature for White-faced Ibis. ${ }^{15}$ In contrast, Glossy lbis nest predominantly in woody vegetation (shrubs and trees) or on the ground. ${ }^{1}$ Water depth at the nest was approximately 1.5 $\mathrm{m}$, which is much deeper than measurements taken at several other White-faced Ibis colonies, but similar to water depth recorded at a colony in Oregon $\quad(1.84$ m). ${ }^{15}$ A second nest of similar size and construction was observed nearby and contained $a$ single pale blue egg. Up to 15 ibis 
were observed departing from among the vegetation surrounding the nest locations, but they could not be confirmed as White-faced lbis.

White-faced lbis are known to nest in association with breeding Franklin's Gulls and Black-crowned Night Herons. 3, 5, 13, 17 Although large numbers of Black-crowned Night-Herons have been observed in and around Whitewater Lake in the past, no nests or individuals of that species were found in the vicinity of the ibis nests. Franklin's Gulls nest in large colonies at Whitewater Lake and the two ibis nests were located adjacent to an area containing numerous Franklin's Gull breeding adults with young.

On September 11, 2005, one of the authors (CA) and Liis Veelma observed a pair of White-faced Ibis with an immature bird at Whitewater Lake. The two adult birds were both identifiable to species by their red irises and facial skin, which retained some red bordered by white (see back cover photograph). The immature bird associated with the two adults in feeding and preening activities (Fig. 3). It was noticeably smaller than the adults with a shorter bill, pale grey on the underparts with a uniform greenish wash on the wings and upperparts, and prominent pale streaking on the head and neck. The iris and legs were dark grey, and the small, narrow area of dark facial skin, which had a barely discernable upper pale border, contrasted strongly with the paler grey face (Fig. 4).

This is the first documented nesting of a Plegadis species in Manitoba. Although the 15 ibis observed near the nests could not be confirmed as Whitefaced, given the number of birds that were present at that exact location, the

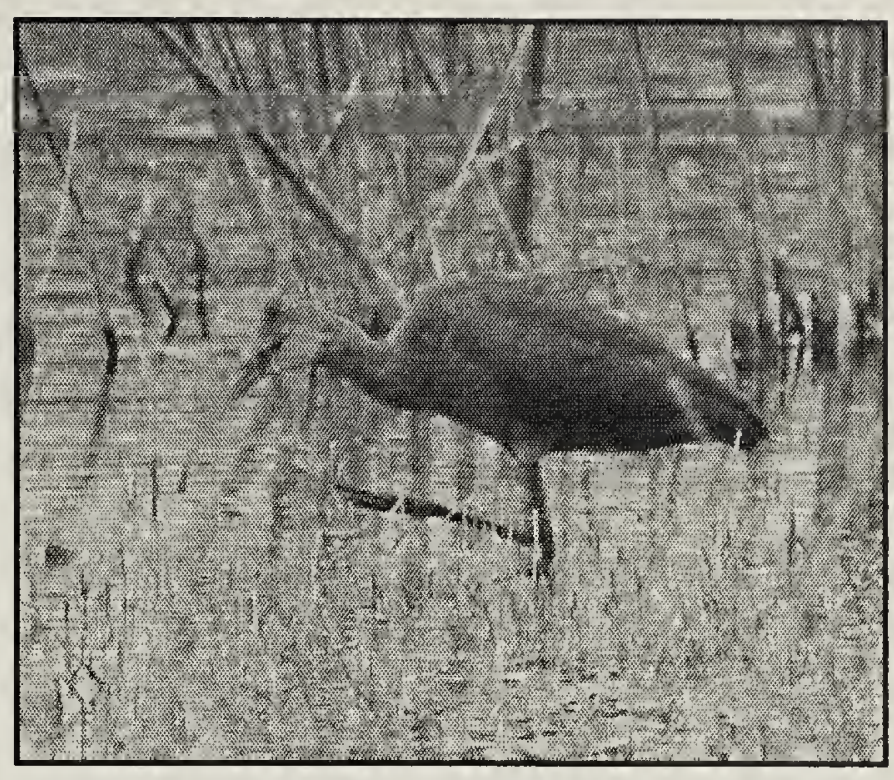

Fig. 4. Immature White-faced Ibis at Whitewater Lake, MB, September 11, 2005

Christian Artuso

number of sightings of that species over the summer at Whitewater Lake (peak count of 20+ White-faced lbis compared to only two Glossy lbis), the description of the nests and eggs, and photographic documentation in late summer of an immature bird associating with a pair of adult Whitefaced lbis $500 \mathrm{~m}$ from the nest site, the evidence strongly suggests that at least one of the nests found at Whitewater Lake was of White-faced Ibis, and very likely both, given the colonial nesting habits of this species. ${ }^{15}$

\section{Acknowledgements}

The authors would like to thank Laura Beaudoin, Rudolf Koes, Paul Goossen and two anonymous reviewers for comments on an earlier version of the manuscript.

1. DAVIS, W.E. and J. KRICHER. 2000. Glossy Ibis (Plegadis falcinellus). In The Birds of North America, No. 130 (A. Poole and F. Gill, Eds.). The Birds of North America Inc., Philadelphia, PA.

2. DICKSON, R. D. 1992. Birding highlights June 1 to August 31, 1992. Pica 12(3): 38-42.

3. GoOSSEN, J. P., D. M. EALEY, H. JUDGE and D. C. DUNCAN. 1995. Distribution and breeding status of the White-faced Ibis, Plegadis chihi, in Canada. Canadian-Field-Naturalist. 109(4): 391-402. 
4. HUDON, J. 2005. The official list of the birds of Alberta: now 400 species and counting... Nature Alberta Spring 2005: 10-14.

5. IVEY G. L., M. A. STERN and C. G. CAREY. 1984. An increasing White-faced lbis population in Oregon. Western-Birds 19: 105-108.

6. KOES, R. F. and P. TAYLOR. 2004. Prairie Provinces. North American Birds 58(1): 93-94.

7. KOES, R. F. and P. TAYLOR. 2005. Prairie Provinces. North American Birds 59(3): 452-453.

8. KOES, R. F. and P. TAYLOR. 2006. Prairie Provinces. North American Birds In press.

9. LAHRMAN, F W. 1976. White-faced Ibis in Saskatchewan. Blue Jay 34: 238.

10. LINDGREN, C. 2001. Community conservation plan for the Whitewater Lake Important Bird Area. Prepared for the Canadian Nature Federation, Bird Studies Canada, BirdLife International and the Manitoba Naturalists Society. Winnipeg, Manitoba. $52 \mathrm{pp}$.

11. MANITOBA AVIAN RESEARCH COMMITTEE. 2003. The Birds of Manitoba. Manitoba Naturalists Society, Winnipeg, Manitoba.
12. MARTIN, R. 2004. Northern Great Plains. North American Birds 57(1): 77-78.

13. PEABODY, P. B. 1896. White-faced glossy ibis breeding in Minnesota. Auk 13: 79.

14. RYDER, R.A. 1967. Distribution, migration and mortality of the White-faced Ibis (Plegadis chihi) in North America. Bird-Banding 38:257-277.

15. RYDER, R.A. and D.E. MANRY. 1994. Whitefaced Ibis (Plegadis chihi). In The Birds of North America, No. 130 (A. Poole and F. Gill, Eds.). The Birds of North America Inc., Philadelphia, PA.

16. SABO, T. 1992. Plegadis ibis - a change in status. Birders Journal 1: 241-256.

17. SCHMIDT, R. A. 1980. First breeding record of the White-faced Ibis in North Dakota. Prairie Naturalist. 12(1):21-23.

18. SERR, E. M. 1978. Northern Great Plains region. American Birds 33: 874-875.

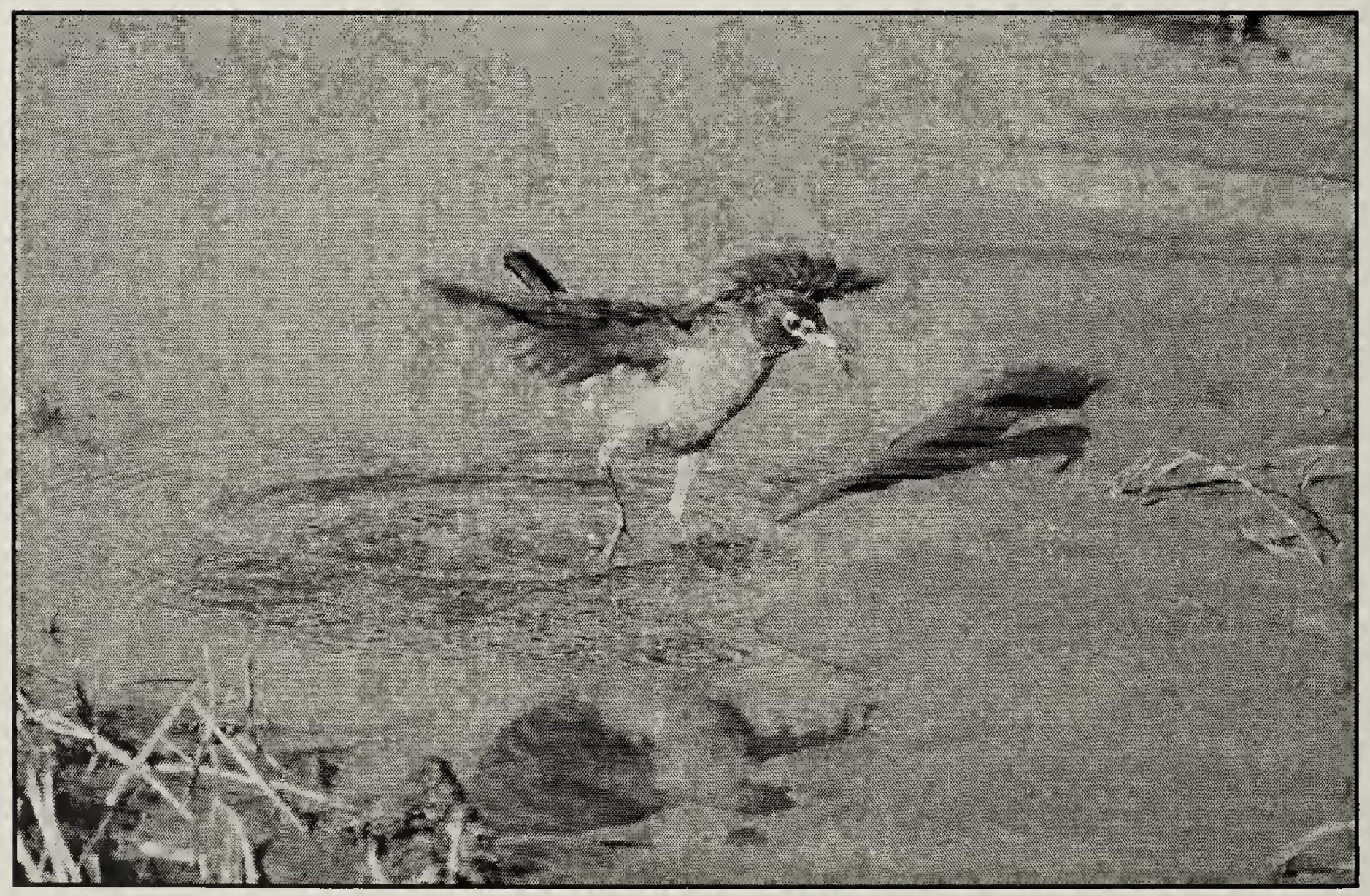

